\title{
Environmental factors affecting thyroid function of wild sea bass (Dicentrarchus labrax) from European coasts
}

\author{
Joseph G. Schnitzler ${ }^{\text {a,*}}$, Peter H.M. Klaren ${ }^{\mathrm{b}}$, Jean-Marie Bouquegneau ${ }^{\mathrm{a}}$, Krishna Das ${ }^{\mathrm{a}}$ \\ ${ }^{a}$ Mare Centre, Laboratory for Oceanology B6c, Liège University, Liège, Belgium \\ ${ }^{\mathrm{b}}$ Radboud Univ. Nijmegen, Inst. Water Wetland Res., Fac. Sci., Dept. Anim. Physiol., Heyendaalseweg 135, NL-6525 AJ Nijmegen, The Netherlands
}

\section{A R T I C L E I N F O}

\section{Article history:}

Received 2 July 2011

Received in revised form 2 November 2011

Accepted 6 November 2011

Available online $\mathrm{xxxx}$

\section{Keywords:}

Dicentrarchus labrax

Persistent organic contaminants

Thyroid hormone metabolism

Deiodination

Glucoronidation

Sulfatation

\begin{abstract}
A B S T R A C T
Thyroid functional status of wild fish in relation with the contamination of their environment deserves further investigation. We here applied a multi-level approach of thyroid function assessment in 87 wild sea bass collected near several estuaries: namely the Scheldt, the Seine, the Loire, the Charente and the Gironde. Thyroxine $\left(\mathrm{T}_{4}\right)$ and triiodothyronine $\left(\mathrm{T}_{3}\right)$ concentrations in muscle were analyzed by radioimmunoassay. The activity of hepatic enzymes involved in extrathyroidal pathways of thyroid hormone metabolism, viz. deiodination, glucuronidation and sulfatation were analyzed. Last, follicle diameter and epithelial cell heights were measured. We observed changes that are predicted to lead to an increased conversion of $T_{4}-T_{3}$ and lowered thyroid hormone excretion. The changes in the metabolic pathways of thyroid hormones can be interpreted as a pathway to maintain thyroid hormone homeostasis. From all compounds tested, the higher chlorinated PCBs seemed to be the most implicated in this perturbation.
\end{abstract}

(c) 2011 Elsevier Ltd. All rights reserved.

\section{Introduction}

Thyroid hormones are essential for normal development, and for maintenance of normal physiological functions in vertebrates (Janz, 2000; Zoeller et al., 2007). In fish, thyroid hormones are involved in the control of osmoregulation, metabolism, somatic growth and post-hatching metamorphosis (Janz, 2000; Power et al., 2001; Yamano, 2005). The regulation of thyroid hormone bioavailability in tissues and cells represents a very complex and unique web of feedback systems (Zoeller et al., 2007). In fish and other vertebrates the thyroid cascade involves two components. First, thyroxine $\left(\mathrm{T}_{4}\right)$ biosynthesis and secretion are largely under central control by the brain-pituitary-thyroid axis (Bernier et al., 2009). Second, there is the conversion of $\mathrm{T}_{4}$ to its biologically active form 3,5,3'-triiodothyronine $\left(\mathrm{T}_{3}\right)$ and its metabolism and receptormediated actions that seems largely to be under peripheral control in extra-thyroidal tissues (Eales and Brown, 1993).

The regulatory mechanisms involved in thyroid hormone homeostasis are numerous and complex. As consequence, environmental chemicals can act at many levels in the thyroid system. The mechanisms involved in the endocrine disruptor mediated alteration of the thyroid function have been extensively investigated but are still not fully understood (Ishihara et al., 2003).

\footnotetext{
* Corresponding author. Tel.: +32 43663328 .

E-mail addresses: joseph.schnitzler@ulg.ac.be (J.G. Schnitzler), p.klaren@scien ce.ru.nl (P.H.M. Klaren), JM.Bouquegneau@ulg.ac.be (J.-M. Bouquegneau), krishna. das@ulg.ac.be (K. Das).
}

The thyroid system is a major target of endocrine disrupting chemicals. Nowadays there are around 116 environmental compounds which are suspected to disrupt thyroid function (Howdeshell, 2002). Numerous environmentally relevant chemicals, including polychlorinated hydrocarbons, polycyclic aromatic hydrocarbons, organochlorine pesticides, chlorinated paraffins, organophosphorous pesticides, carbamate pesticides, cyanide compounds, methyl bromide, phenols, ammonia, metals, acid loads, sex steroids, and pharmaceuticals, exert acute or chronic effects on the thyroid cascade in the approximately 40 teleost fish species tested to date (Brucker-Davis, 1998; Rolland, 2000; Brown et al., 2004; Blanton and Specker, 2007).

The effects of PCB mixtures on the thyroid system have been examined extensively in vertebrates. Brouwer et al. have compiled an excellent review on the interactions of persistent organohalogens, including PCBs, on the thyroid status in mammals and birds. In general, PCB mixtures increase the metabolism and excretion of thyroid hormones and lower circulating $\mathrm{T}_{4}$ levels (Brouwer et al., 1998). Research on fish reported changes in the histology of the thyroid gland and in plasma thyroid hormone levels in coho salmon (Oncorhynchus kisutch), chinook salmon (Oncorhynchus tshawytscha), rainbow trout (Oncorhynchus mykiss) and flounder (Platichthys flesus) (Leatherland and Sonstegard, 1978, 1980; Leatherland, 1993; Besselink et al., 1996). Overall, these studies indicate that PCB mixtures can alter indices of thyroid status in fish but their mode of action is not well understood.

Organochlorine pesticides including p,p'-dichlorodi-phenyltrichloroethane (DDT) and hexachlorocyclo-hexanes, can alter thyroid 
function. Tilapia (Oreochromis mossambicus) exposed to DDT showed greater thyroid epithelial cell height and nuclear diameter (Shukla and Pandey, 1986), indicative of increased thyroid gland activity. Mullet (Liza parsia) exposed to DDT displayed opposite symptoms such as a decrease in thyroid epithelial cell height, degeneration of epithelial cells, and depletion of colloid (Pandey et al., 1995). Exposure to lindane, the gamma isomer of hexachlorocyclohexane $(\gamma-\mathrm{HCH})$, increased plasma $\mathrm{T}_{4}$ levels but decreased plasma $T_{3}$ levels in $H$. fossilis (Yadav and Singh, 1987), whereas a similar treatment induced no differences in serum $\mathrm{T}_{4}$ in rainbow trout (Aldegunde et al., 1999). The $\beta$-isomer of hexachlorocyclohexane induced thyrocyte hypertrophyand a diminished colloid content in the thyroid gland's follicles, and also an increase in the number of pituitary thyrotropes in medaka (Oryzia latipes) (Wester and Canton, 1988). All in all, organochlorine pesticides have multiple and species-specific effects in teleostean species, and a general picture cannot, as yet, be constructed.

Our current knowledge is derived mostly from laboratory studies on the effects of endocrine disrupting chemicals in fish (Adams et al., 2000; Brown et al., 2004; Boas et al., 2006; Leroy et al., 2006). Only a very small number of studies have assessed the effects of the environmental pollution on wild animals, and most of them concern the influence of PCBs on the thyroid system of Great Lakes organisms (Leatherland et al., 1989b; Leatherland and Down, 2001; Raine, 2001). The interpretation of the results from field studies is proving to be more difficult because of normal variations in thyroid hormones associated with age, gender, diet, nutritional status, season and physiological condition (Rolland, 2000).

To our knowledge no comprehensive study has been carried out in European waters. Concentrations of organic contaminants in fishes may vary widely in relation to feeding habits, the nature of the habitat and environmental factors such as coastal marine pollution (Loizeau, 2001; Lewis et al., 2002; Naso et al., 2005). In European waters, $\mathrm{PCBs}$ concentration in tissues from juvenile sea bass varied from $130 \mathrm{ng} \mathrm{g}^{-1}$ (lw) in Gironde to $5380 \mathrm{ng} \mathrm{g}^{-1}$ (lw) in Scheldt (Schnitzler et al., 2011), with unknown consequences for their thyroid function (Fig. 1). This study therefore aimed at establishing a correlation between exposures to contaminants and effects on the thyroid endocrine system. To this end, we investigated the thyroid status of wild sea bass collected near major estuaries of European coastlines: the Scheldt, the Seine, the Loire, the Charente and the Gironde. In order to examine the status of thyroid function at multiple levels, we have studied simultaneously different endpoints. The centrally controlled thyroidal secretion of $\mathrm{T}_{4}$ was monitored from muscular $\mathrm{T}_{4}$ levels and thyroid

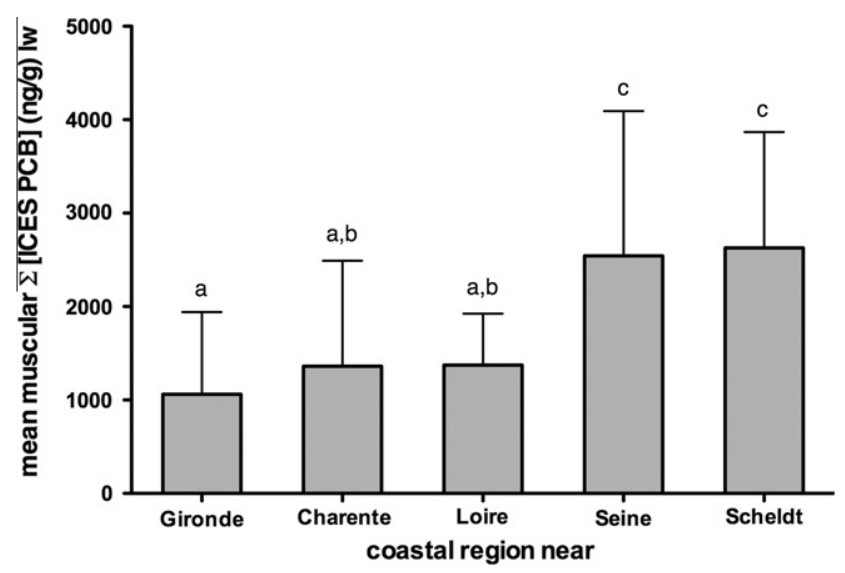

Fig. 1. Differences in muscular [7ICES PCB] concentrations in sea bass from coastal regions near European river mouths. gland histology. The peripherally controlled conversion of $T_{4}-T_{3}$ was monitored by in-vitro deiodination activities, and muscular $\mathrm{T}_{3}$ levels were measured to reflect peripheral thyroidal $\left(\mathrm{T}_{3}\right)$ status. We applied multivariate statistical analysis to identify associations between chronic exposition to previously described organic pollutants (Schnitzler et al., 2011) and thyroid function in wild sea bass.

\section{Materials and methods}

\subsection{Sampling}

Eighty seven sea bass (Dicentrarchus labrax) were collected between 20th September and 1st November 2007 during different scientific missions of CEMAGREF (Institut de recherche pour l'ingénierie de l'agriculture et de l'environnement), IFREMER (Institut Français de Recherche pour l'Exploitation de la Mer) and INBO (Instituut voor Natuur-en Bosonderzoek) as previously described (Schnitzler et al., 2011). Sea bass were caught in the coastal regions of the European rivers Gironde, Charente, Loire, Seine, and Scheldt.

The caught fish were immediately dissected. The length and the weight of each fish were measured. Gonads were inspected to sex the fish and to evaluate the macroscopic characteristics of the maturity stages of the ovary and testes of sea bass. Approximately $30 \mathrm{~g}$ of skeletal muscle was excised from the area directly caudal to the head, dorsal to the lateral line and anterior to the dorsal fin. The muscle samples were stored at $-70^{\circ} \mathrm{C}$ until analysis.

\subsection{Standards and reagents}

Thyroxine $\left(\mathrm{T}_{4}\right)$, uridine $5^{\prime}$-diphosphate glucuronic acid (UDPGA) and $3^{\prime}$-phospho-adenosine-5'-phosphosulfate (PAPS), were from Sigma Chemical Co. (St. Louis, MO). Sephadex LH-20 was purchased from Amersham Pharmacia Biotech Benelux (Roosendaal, The Netherlands). Outer ring labeled $\left[{ }^{125} \mathrm{I}\right] \mathrm{T}_{4}(23.3 \mathrm{TBq} / \mathrm{mmol})$ was obtained from Perkin-Elmer Life Science, Inc. (Boston, MA). All other chemicals were analytical grade and obtained from commercial suppliers. Radiolabeled iodothyronines were purified shortly before use by Sephadex LH-20 column chromatography. Radioactivities were measured in a 1272-Clinigamma gamma counter (LKB/Wallac Oy, Turku, Finland). Protein concentrations were determined using a Coomassie Brilliant Blue G-250 kit (BioRad, München, Germany) and bovine serum albumin as a standard.

\subsection{Muscular thyroid hormone determinations}

Total $\mathrm{T}_{3}$ and $\mathrm{T}_{4}$ concentrations in extracts of muscle samples were measured by radio immunoassay (Siemens Coat-a-Count, Brussels, Belgium) according to the manufacturer's instructions. Details of extraction methods and the elaborated assay protocol are described elsewhere (Schnitzler et al., 2008). The accuracy of the assay was determined by blind analysis of spiked samples at high, medium and low concentrations. These samples were inserted in duplicate at the front, middle and end of the assay and mean measured concentrations were then compared to actual concentrations to determine assay reliability. The assay was accepted with reliability between 90 and $110 \%$. To determine the efficacy of the extraction process in recovering thyroid hormones as well as transfer of samples into different types of tubes, a recovery systems were used. Unlabeled thyroid hormone was added to the minced fish muscle prior to homogenization. The samples were then subjected to the same homogenization, extraction, reconstitution and thyroid hormone assay procedures as the unknown and standard curve samples. The percentage of thyroid hormone recovered from each spiked tube was calculated and revealed quantitative recoveries of $92 \% \mathrm{~T}_{4}$ and $93 \% \mathrm{~T}_{3}$. 


\subsection{Tissue preparations for enzymatic activity tests}

Liver from sea bass and were homogenized in $3 \mathrm{ml}$ phosphate buffer [ $100 \mathrm{mmol} / \mathrm{l} \mathrm{Na-phosphate} \mathrm{(pH} \mathrm{7.2),} 2$ mmol/l EDTA] in a glass dounce homogenizer equipped with a tightly fitting Teflon pestle. Homogenates were stored at $-80^{\circ} \mathrm{C}$ until further analysis. Protein was measured with a commercial Coomassie Brilliant Blue reagent kit (Bio-Rad Laboratories, München, Germany) using BSA as a reference.

\subsection{Sulfotransferase activity}

Sulfotransferase activities were measured in duplicate with $\mathrm{T}_{4}$ as conjugate group acceptors. PAPS was used as the sulfate group donor. Sulfotransferase activity towards $\mathrm{T}_{4}$ was measured by the incubation of approximately $50 \mu \mathrm{g}$ homogenate protein at $37^{\circ} \mathrm{C}$ for $120 \mathrm{~min}$ in $200 \mu$ l buffer composed of $100 \mathrm{mM}$ Na-phosphate buffer and $2 \mathrm{mM}$ EDTA (pH 7.2), $1 \mu \mathrm{M}^{125}$ I-labeled $\mathrm{T}_{4}$ and $50 \mu \mathrm{M}$ PAPS. The reaction was terminated with $800 \mu \mathrm{l}$ ice-cold $0.1 \mathrm{M} \mathrm{HCl}$, and the quenched incubate was applied to Sephadex LH-20 mini-columns ( $2 \mathrm{ml}$ of a $10 \% \mathrm{w} / \mathrm{v}$ suspension) to resolve liberated iodide, water-soluble conjugates and native iodothyronines, respectively, as described in detail previously (van der Heide et al., 2002). Radioiodide activities in the water-soluble fractions were interpreted to have originated from the presence of sulfated iodothyronines. Control incubations in these assays were in the absence of PAPS. Net sulfotransferase activities are expressed as a percentage of the total sum of all fractions of the Sephadex LH-20 chromatograms.

\subsection{UDP glucuronyltransferase activity (UGT)}

UGT activities were measured in duplicate with $\mathrm{T}_{4}$ as conjugate group acceptors. UDPGA was used as the glucuronosyl group donor. The glucuronidation of $\mathrm{T}_{4}$ was measured by the incubation of $50 \mu \mathrm{g}$ homogenate protein at $37^{\circ} \mathrm{C}$ for $120 \mathrm{~min}$ in $200 \mu \mathrm{l}$ buffer containing $100 \mathrm{mM}$ Tris/ $\mathrm{HCl}\left(\mathrm{pH} 7.4\right.$ ), $5 \mathrm{mM} \mathrm{MgCl}_{2}$ and $0.05 \%$ Brij56, supplemented with $1 \mu \mathrm{M}^{125}$ I-labeled $\mathrm{T}_{4}$ and 5 mM UDPGA. The reaction was quenched with $200 \mu$ ice-cold methanol, and the incubate was centrifuged for $10 \mathrm{~min}$ at $1500 \mathrm{~g}$. To $300 \mu \mathrm{l}$ of the supernatant thus obtained $700 \mu \mathrm{l} 0.1 \mathrm{M} \mathrm{HCl}$ was added, and the mixture was subjected to Sephadex LH-20 column chromatography as described above. Radioiodide activities in the water-soluble fractions were here interpreted to have originated from the presence of glucuronidated iodothyronines. Control incubations were in the absence of UDPGA.

\subsection{Outer ring deiodinase activity (ORD)}

5'-Deiodinase activities were measured in duplicate as described in detail elsewhere (Klaren et al., 2005). Briefly, $50 \mu$ g homogenate protein was incubated under saturating substrate conditions of $20 \mu \mathrm{M} \mathrm{T}_{4}$ in $200 \mu \mathrm{l}$ of $100 \mathrm{mM}$ Na-phosphate buffer ( $\mathrm{pH}$ 7.2). Outer ring labeled $\left[{ }^{125} \mathrm{I}\right] \mathrm{T}_{4}$ was used as a tracer, and was purified on a $10 \%(w / v)$ Sephadex LH-20 mini-column shortly before use. The reaction was quenched by the addition of $100 \mu \mathrm{l}$ ice-cold 5\% BSA, followed by $500 \mu \mathrm{l}$ ice-cold $10 \%$ TCA, and centrifuged at $1400 \mathrm{~g}$ $\left(15 \mathrm{~min}, 4^{\circ} \mathrm{C}\right.$ ). To the obtained $500 \mu \mathrm{l}$ of the deproteinised supernatant, we added an equal volume of $1.0 \mathrm{M} \mathrm{HCl}$, and liberated iodide was separated from the native iodothyronine using Sephadex LH-20 column chromatography. Non-enzymatic outer ring deiodination was determined in the absence of a preparation.

\subsection{Thyroid histomorphometric analysis}

The thyroid tissues enclosed in the subpharyngeal area were fixed in $10 \%$ salt water buffered formalin for $24 \mathrm{~h}$ at room temper- ature. The tissues were randomly mixed and processed together in order to avoid biases and artefacts due to fixation conditions, dehydration and embedding. The tissue was then decalcified in $5 \%$ formic acid and 5\% formaldehyde for $1 \mathrm{~d}$ and transferred to a $22.2 \%$ sodium sulfate solution for another day. The tissues were dehydrated in a graded series of ethanol before being embedded in paraffin wax. The paraffin blocks were longitudinally sectioned $(8 \mu \mathrm{m})$ through all the thyroid tissues. The hematoxylin-eosin stain method was used for the microscopically diagnostic study of the histological samples.

The microscopic analyses were done without knowledge of the fish provenance and contamination burden. Images of 50 randomly selected follicles per fish at 100 times magnification were analyzed. Thyroid histomorphometry was measured using Macnification $^{\circledR}$ software (version 1.6.1 Orbicule Enhanced Labs). The different measurements in the thyroid tissue were determined by manually marking the contours of the follicles in the tissue. The follicle area, perimeter, diameter, length and width of every follicle cross section were thus measured. The shapes of the follicles were described with three dimensionless shape descriptors: roundness, form factor and aspect ratio, which were calculated as follows:

Roundness $=4$ Area $\left(\mu \mathrm{m}^{2}\right) / \pi$ Diameter $^{2}(\mu \mathrm{m})$. A follicle with a maximum roundness value of 1 perfectly resembles a circle.

Form factor $=4 \pi$ Area $\left(\mu \mathrm{m}^{2}\right) /$ Perimeter $^{2}(\mu \mathrm{m})$. The form factor expresses the evenness of the follicles outline; as its value approaches 1 , the outline resembles a circle.

Aspect ratio $=$ maximum length $(\mu \mathrm{m}) /$ maximum with $(\mu \mathrm{m})$. The larger the aspect ratio, the more elongated the follicle is; a ratio of 1 corresponds to a perfectly circular follicle.

\subsection{Chemical analysis}

Extracts of $10 \mathrm{~g}$ of dorsal muscular tissue of each fish were analyzed for polychlorinated biphenyls (PCBs), dichloro-diphenyl-trichloroethane (DDT), hexachlorocyclohexanes (HCHs), aldrin and dieldrin by gas chromatography using a Thermo Quest Trace 2000 gas chromatograph equipped with a 63Ni ECD (Thermo Quest, Trace 2000). Detailed method and results are presented elsewhere (Schnitzler et al., 2008, 2011).

\subsection{Calculations and statistics}

Mean values \pm standard deviation, (median) and min-max are presented, unless indicated otherwise. Pollutant concentrations are normalized for fresh (wet) tissue weight and the thyroid hormone concentrations and metabolic activities are also expressed on wet weight basis.

Statistical analysis of the data was performed using SPSS for Mac ${ }^{\circledR}$ software (SPSS Inc., version 16.0.2). The Kolmogorov-Smirnoff test was used to test for normality of the statistically treated variables. The non-parametric Mann-Whitney $U$-test was used to compare differences in organochlorine compound concentrations between sexes and correlation tests followed by Fishers Omnibus post-hoc tests were used to compare differences in organochlorine compound concentrations in relation to length and weight.

Intersite comparison of the thyroid parameters were realized using an analysis of variance (ANOVA) to compare means between the different collection locations followed by Tukey's multiple comparisons post-hoc tests. The relationships between thyroid parameters (follicle histomorphometry, thyroid hormone concentrations and enzyme activities) and toxicological data were analyzed in two steps. First, a correlation test was used to identify the contaminants related to the thyroid parameters. Then a correlation-based principal component analysis (PCA) was performed to reduce the 24 identified contaminant variables in order to avoid 
misleading results due to correlating independent variables ('multi-collinearity') in subsequent analysis. Thereafter a correlation test, with the four factor scores revealed by the PCA as independent variables and thyroid parameters as dependent variable, was applied. Results were considered significant when $p<0.05$.

\section{Results}

\subsection{Sampling}

Overall mean body length of the collected sea bass was $31 \pm 4.6 \mathrm{~cm}(n=87)$. There were no significant differences in mean body length and weight between sampling locations. Based upon available length and age data, all sea bass were estimated to be juveniles 1-2 years of age. Inspection of the gonads confirmed that all sea bass were sexually immature. The overall sex ratio was 1:1 male:female. Neither size (length and weight) (Spearman correlation tests followed by Fisher Omnibus post-hoc test; $p>0.05$ ), nor sex (Mann-Whitney; $p>0.05$ ) had a significant interaction with any of the toxicological and endocrine parameters in this study.

\subsection{Organochlorine compound analysis}

The complete toxicological analysis including contamination levels, intersite comparisons, profile analysis and an estimate of risk for human consumption is published separately (Schnitzler et al., 2011). This study shows that juvenile sea bass from Scheldt and Seine had higher levels of organochlorine pesticides compared to sea bass collected near the Loire, Charente and Gironde (Fig. 1).

\subsection{Intersite differences in thyroid parameters}

Thyroid hormone tissue levels varied significantly between locations (ANOVA, $p<0.001$ in both cases, Table 1 ). The highest $\mathrm{T}_{4}$ and $\mathrm{T}_{3}$ concentrations were observed in sea bass from Charente and Loire coastal regions whereas the lowest levels were measured in sea bass from the Seine and the Scheldt.

Analysis of thyroid gland tissue by light microscopy revealed irregular or oval follicular lumens surrounded by follicular epithelial cells. The epithelial cells were flattened, cuboid or columnar (Fig. 2). The histomorphometrical analysis of the thyroid tissue revealed differences in epithelial cell heights (ANOVA, $p<0.05$ ). The follicles observed in sea bass from the coastal region near the rivers Charente and Loire were larger and surrounded by higher epithelial cells than those measured in sea bass from the coastal regions near the Seine and the Scheldt. However, follicle size, roundness, form factor and aspect ratio remained similar between locations (ANOVA, $p>0.05$ ) (Table 1).

Outer ring deiodination (ORD) activities were detected in sea bass livers samples and differed significantly between locations (ANOVA, $p<0.001$ ). The activity of ORD was significantly lower in sea bass from Charente and Loire coastal regions whereas the highest activities were measured in the liver of sea bass from the Seine and the Scheldt (Table 1). Glucuronidation and sulfatation were similar between locations (ANOVA, $p>0.05$ ).

\subsection{Relationships between thyroid endocrine status and contaminant exposure}

Environmental levels of higher chlorinated PCB congeners (IUPAC nos. 112, 153, 170, 180, 183, 194 and 195) correlated negatively with the $T_{4}$ and $T_{3}$ concentrations in skeletal muscle ( $R=-0.220$ to -0.310 and $R=-0.212$ to -0.369 respectively). Levels of CB congeners 52 70, 87, 95, 101, 110, 118, 128, 138, $153,156,170,180,183,187,194$ and 195 correlated positively with hepatic ORD activity $(R=0.228-0.551)$. Levels of DDD metabolites correlated negatively with skeletal muscle $T_{3}$ concentrations, and positively hepatic ORD activity $(R=-0.358$ and 0.351 respectively). HCHs concentrations correlated positively with muscular $\mathrm{T}_{4}$ and $\mathrm{T}_{3}$ concentrations and negatively with the hepatic ORD activity $(R=0.224-0.381$ and $0.426-0.502$ respectively. Finally we observed a negative correlation between the muscular $\mathrm{T}_{3}$ concentration, and a positive correlation between hepatic ORD activity and dieldrin levels, whereas aldrin has no effect on any thyroid parameter measured ( $R=-0.273$ and 0.551 respectively). With respect to the other thyroid parameters (i.e., thyroid gland morphology, glucuronidation and sulfatation) no relationship with environmental contaminants could be revealed in this study.

A principal component analysis permitted us to reduce the 24 organochlorine compound variables (18 PCB congeners IUPAC nos. 52, 70, 87, 95, 101, 110, 118, 128, 138, 153, 156, 170, 180, $183,187,194$ and 195 and the pesticides $p p^{\prime}$-DDT, $p p^{\prime}$-DDE, $p p^{\prime}-$ $\mathrm{DDD}, \alpha \mathrm{HCH}, \beta \mathrm{HCH}, \chi \mathrm{HCH}$ and dieldrin), identified to have an effect on the thyroid system, to four principal components. The four components explain $77.7 \%$ of the total variance. The first component represents the PCB congeners with a lower degree of chlorination (tetra-, penta- and hexa-chlorobiphenyls), whereas the second component represents higher chlorinated PCB congeners (heptaand octa-chlorobiphenyls) and $p p^{\prime}$-DDT and $p p^{\prime}$-DDE. The third component regroups the three $\mathrm{HCH}$ isomers and the fourth represents mainly the $p p^{\prime}$-DDD metabolite (Table 2).

Correlation tests were used to evaluate the effects of the different components on the thyroid parameters. No significant relationship could be revealed between the first component and the thyroid parameters. The second component revealed several significant relationships, a negative correlation with the muscular $\mathrm{T}_{3}$ concentration $(R=-0.23, p=0.030)$, a strong positive correlation with the hepatic ORD activity $(R=0.42, p<0.001)$ and a negative correlation with the sulfatation activity $(R=-0.48, p=0.045)$ (Fig. 3$)$. Significant positive correlations were observed between the third component and the muscular $\mathrm{T}_{4}$ and $\mathrm{T}_{3}$ concentrations $(R=0.39$ and 0.49 respectively $p<0.001)$ and a negative correlation with the hepatic ORD activity $(R=-0.33, p=0.002)$. Finally the fourth component could be associated to the muscular $\mathrm{T}_{3}$ concentration ( $R=-0.31, p=0.004)$, the epithelial cell height and follicle roundness $(R=-0.30$ and $R=0.35$ respectively $p<0.05$ ) (Table 2 ).

\section{Discussion}

Sea bass can accumulate various PCB congeners and other chlorinated compounds in their tissues. The levels measured in sea bass are generally the highest measured in edible marine fish species (Naso et al., 2005). This probably reflects their feeding habits and the nature of the habitat of these benthic and euryhaline species which usually inhabits shallow waters with sandy or muddy bottoms along the coast, and ports and estuaries, which are generally considered to be more heavily polluted than open waters (Loizeau, 2001; Lewis et al., 2002). Recently, we showed that pesticide levels in juvenile sea bass from Scheldt and Seine are higher than in sea bass collected near the Loire, Charente and Gironde (Schnitzler et al., 2011), and it can be concluded that sea bass tissue pesticide concentrations reflect the environmental pesticide load.

\subsection{Intersite differences in thyroid parameters}

The muscular thyroid hormone concentrations are in the same range as those observed in previous studies on sea bass (Schnitzler et al., 2008), and are comparable to other investigations into tissue thyroid hormone concentrations. Total $\mathrm{T}_{4}$ and $\mathrm{T}_{3}$ concentrations have been measured in extracts from whole eggs, yolk, larvae and 
Table 1

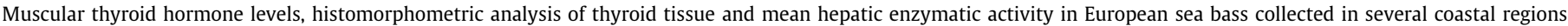
(results are presented in mean \pm standard deviation, (median), range).

\begin{tabular}{|c|c|c|c|c|c|c|}
\hline Coastal region near & Gironde & Charente & Loire & Seine & Scheldt & ANOVA \\
\hline$n$ & 8 & 8 & 34 & 26 & 11 & \\
\hline $\mathrm{T}_{4}\left(\mathrm{ng} \mathrm{g}^{-1}\right)$ & $\begin{array}{l}12.0 \pm 4.1 \\
(11.9) \\
3.6-17.1\end{array}$ & $\begin{array}{l}15.2 \pm 2.5 \\
(14.8) \\
12.7-18.2\end{array}$ & $\begin{array}{l}14.0 \pm 5.1 \\
(15.4) \\
2.5-20.3\end{array}$ & $\begin{array}{l}7.3 \pm 5.5^{a} \\
(5.4) \\
0.6-18.6\end{array}$ & $\begin{array}{l}5.3 \pm 3.1^{\mathrm{a}} \\
(4.7) \\
1.7-11.4\end{array}$ & $\begin{array}{l}F(4,83)=12.4 \\
\boldsymbol{p}<\mathbf{0 . 0 0 1}^{*}\end{array}$ \\
\hline $\mathrm{T}_{3}\left(\mathrm{ng} \mathrm{g}^{-1}\right)$ & $\begin{array}{l}0.83 \pm 0.54 \\
(0.56) \\
0.47-1.78\end{array}$ & $\begin{array}{l}1.52 \pm 0.45^{\mathrm{a}} \\
(1.51) \\
0.88-2.15\end{array}$ & $\begin{array}{l}1.68 \pm 0.50^{\mathrm{a}} \\
(1.61) \\
0.79-2.62\end{array}$ & $\begin{array}{l}1.29 \pm 0.42^{\mathrm{a}} \\
(1.23) \\
0.49-2.25\end{array}$ & $\begin{array}{l}0.95 \pm 0.10 \\
(0.94) \\
0.86-1.17\end{array}$ & $\begin{array}{l}F(4,83)=10.1 \\
\boldsymbol{p}<\mathbf{0 . 0 0 1}^{*}\end{array}$ \\
\hline Follicle diameter $(\mu \mathrm{m})$ & $\begin{array}{l}74 \pm 15 \\
(74) \\
63-85\end{array}$ & $\begin{array}{l}85 \pm 24 \\
(83) \\
64-111\end{array}$ & $\begin{array}{l}75 \pm 20 \\
(72) \\
45-124\end{array}$ & $\begin{array}{l}64 \pm 14 \\
(63) \\
43-84\end{array}$ & $\begin{array}{l}58 \pm 12 \\
(56) \\
43-75\end{array}$ & $\begin{array}{l}F(4,40)=2.1 \\
p=0.099\end{array}$ \\
\hline Cell height $(\mu \mathrm{m})$ & $\begin{array}{l}17 \pm 3 \\
(17) \\
15-19\end{array}$ & $\begin{array}{l}17 \pm 4 \\
(16) \\
14-23\end{array}$ & $\begin{array}{l}16 \pm 2 \\
(17) \\
12-22\end{array}$ & $\begin{array}{l}14 \pm 4^{\mathrm{a}} \\
(14) \\
8-19\end{array}$ & $\begin{array}{l}13 \pm 4^{\mathrm{a}} \\
(13) \\
8-19\end{array}$ & $\begin{array}{l}F(4,40)=2.6 \\
\boldsymbol{p}=\mathbf{0 . 0 4 5}^{*}\end{array}$ \\
\hline Roundness & $\begin{array}{l}0.81 \pm 0.01 \\
(0.81) \\
0.80-0.82\end{array}$ & $\begin{array}{l}0.83 \pm 0.02 \\
(0.83) \\
0.81-0.85\end{array}$ & $\begin{array}{l}0.79 \pm 0.03 \\
(0.79) \\
0.72-0.84\end{array}$ & $\begin{array}{l}0.80 \pm 0.03 \\
(0.81) \\
0.74-0.85\end{array}$ & $\begin{array}{l}0.81 \pm 0.04 \\
(0.81) \\
0.74-0.85\end{array}$ & $\begin{array}{l}F(4,40)=1.2 \\
p=0.308\end{array}$ \\
\hline Form factor & $\begin{array}{l}0.83 \pm 0.01 \\
(0.83) \\
0.82-0.84\end{array}$ & $\begin{array}{l}0.84 \pm 0.02 \\
(0.84) \\
0.82-0.86\end{array}$ & $\begin{array}{l}0.81 \pm 0.03 \\
(0.81) \\
0.76-0.86\end{array}$ & $\begin{array}{l}0.82 \pm 0.03 \\
(0.82) \\
0.75-0.86\end{array}$ & $\begin{array}{l}0.82 \pm 0.04 \\
(0.82) \\
0.75-0.86\end{array}$ & $\begin{array}{l}F(4,40)=1.0 \\
p=0.416\end{array}$ \\
\hline Aspect ratio & $\begin{array}{l}1.20 \pm 0.20 \\
(1.20) \\
1.06-1.35\end{array}$ & $\begin{array}{l}1.33 \pm 0.11 \\
(1.34) \\
1.20-1.46\end{array}$ & $\begin{array}{l}1.28 \pm 0.22 \\
(1.23) \\
0.95-1.72\end{array}$ & $\begin{array}{l}1.01 \pm 0.19^{\mathrm{a}} \\
(0.90) \\
0.79-1.35\end{array}$ & $\begin{array}{l}0.91 \pm 0.14^{\mathrm{a}} \\
(0.89) \\
0.79-1.18\end{array}$ & $\begin{array}{l}F(4,40)=6.3 \\
\boldsymbol{p}<\mathbf{0 . 0 0 1}^{*}\end{array}$ \\
\hline Deiodinase activity (fmol $\min ^{-1} \mu \mathrm{g}^{-1}$ ) & $\begin{array}{l}23.2 \pm 10.4^{\mathrm{c}} \\
(25.9) \\
9.9-38.0\end{array}$ & $\begin{array}{l}5.8 \pm 2.7^{\mathrm{a}} \\
(5.0) \\
3.3-11.2\end{array}$ & $\begin{array}{l}11.5 \pm 6.3^{\mathrm{b}} \\
(9.7) \\
2.8-33.7\end{array}$ & $\begin{array}{l}17.6 \pm 7.0^{\mathrm{b}} \\
(15.4) \\
8.6-39\end{array}$ & $\begin{array}{l}15.1 \pm 3.9^{\mathrm{b}} \\
(13.3) \\
11.3-22.1\end{array}$ & $\begin{array}{l}F(4,83)=9.4 \\
\boldsymbol{p}<\mathbf{0 . 0 0 1}^{*}\end{array}$ \\
\hline Sulfation activity (fmol $\min ^{-1} \mu \mathrm{g}^{-1}$ ) & $\begin{array}{l}0.3 \pm 0.3 \\
(0.3) \\
0.01-0.71\end{array}$ & $\begin{array}{l}1.5 \pm 1.2 \\
(1.1) \\
0.40-3.16\end{array}$ & $\begin{array}{l}1.5 \pm 1.4 \\
(1.4) \\
0.04-3.16\end{array}$ & $\begin{array}{l}1.3 \pm 0.6 \\
(1.4) \\
0.45-1.76\end{array}$ & $\begin{array}{l}1.0 \pm 0.7 \\
(1.0) \\
0.46-1.74\end{array}$ & $\begin{array}{l}F(4,16)=1.1 \\
p=0.392\end{array}$ \\
\hline Glucuronidation activity ( $\mathrm{fmol} \mathrm{min}^{-1} \mu \mathrm{g}^{-1}$ ) & $\begin{array}{l}6.9 \pm 2.5 \\
(6.4) \\
3.1-8.3\end{array}$ & $\begin{array}{l}8.3 \pm 3.8 \\
(8.9) \\
3.6-11.6\end{array}$ & $\begin{array}{l}9.9 \pm 3.3^{a} \\
(10.6) \\
6.6-11.6\end{array}$ & $\begin{array}{l}3.3 \pm 2.2 \\
(2.2) \\
0.2-8.7\end{array}$ & $\begin{array}{l}6.1 \pm 1.4 \\
(6.0) \\
4.6-7.9\end{array}$ & $\begin{array}{l}F(4,16)=2.9 \\
p=0.057\end{array}$ \\
\hline
\end{tabular}

abc significant after Tukey's multiple comparisons.

Significant ANOVA at the 0.05 level.

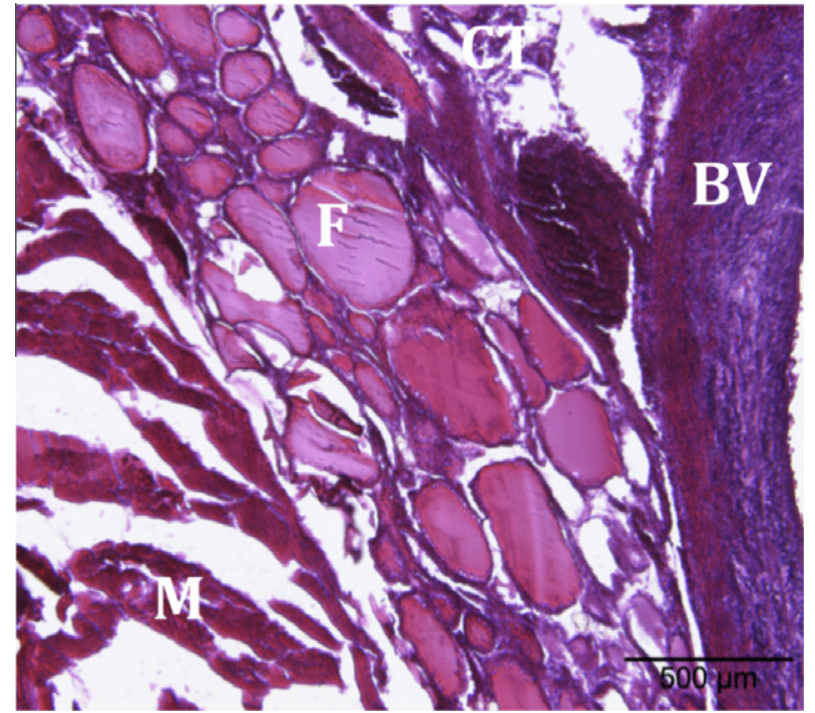

Fig. 2. Longitudinal section of European sea bass thyroid tissue in subpharyngeal area (H.E. staining; $\mathrm{BV}=$ ventral aorta $; \mathrm{F}=$ follicle $; \mathrm{M}=$ muscle; $\mathrm{CT}=$ connective tissue).

fry of salmonids (Tagawa and Hirano, 1987; Leatherland et al., 1989a,b; de Jesus and Hirano, 1992), flounder (Tagawa et al., 1990a), striped bass (Morone saxatilis, Percichthyidae) (Parker and Specker, 1990), the conger eel (Conger conger, Anguillidae) (Yamano et al., 1991), the tilapia (O. mossambicus, Cichlidae) (Weber et al., 1992) and other species (Tagawa et al., 1990b). The concentrations vary between the different species, but they do support the roles of thyroid hormones in early development and during metamorphosis. Muscle contains low amounts of $\mathrm{T}_{3}$, but owing to its large mass comprises a total tissue pool representing about $80 \%$ of all the $\mathrm{T}_{3}$ in the rainbow trout (Fok et al., 1990). The muscular thyroid hormone concentrations should thus provide a good index of the thyroid hormone reserves in fish.

Thyroid parameters differed between sampling locations suggesting environmental influence on endocrine activities. Sea bass from the more contaminated locations, showed lower muscular thyroid hormone concentrations, smaller follicles surrounded by epithelial cells with a less pronounced cell height, and with a higher hepatic ORD activity. Levels of thyroid hormones can be influenced by many other factors including age, gender, diet, nutritional status, season and physiological condition (Rolland, 2000). We therefore designed the study to control for these variables, i.e., sampling was carried out in a short period of time in autumn when the weather conditions were fairly stable. As neither body size (length and weight) nor sex had a significant interaction with any endocrine parameters in this study, endocrine disrupting chemicals are likely to be a causative independent variable.

\subsection{Relationships between thyroid endocrine status and contaminant exposure}

Multivariate analysis revealed complex interactions between previously published pollutant concentrations (Schnitzler et al., 
Table 2

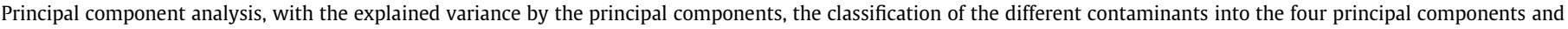
the results of the multivariate correlation tests (significant $p$-values are in bold).

\begin{tabular}{|c|c|c|c|c|}
\hline & Fact. 1 & Fact. 2 & Fact. 3 & Fact. 4 \\
\hline$\%$ of total variance & 30.3 & 27.0 & 11.5 & 8.9 \\
\hline Cumulative variance \% & 30.3 & 57.3 & 68.8 & 77.7 \\
\hline IUPAC\#52 & 0.47 & 0.37 & -0.20 & 0.37 \\
\hline IUPAC\#70 & 0.83 & 0.16 & 0.05 & 0.41 \\
\hline IUPAC\#87 & 0.69 & 0.17 & -0.07 & 0.57 \\
\hline IUPAC\#95 & 0.84 & 0.28 & 0.02 & 0.32 \\
\hline IUPAC\#101 & 0.83 & 0.36 & -0.26 & 0.17 \\
\hline IUPAC\#110 & 0.81 & 0.30 & 0.00 & 0.00 \\
\hline IUPAC\#118 & 0.86 & 0.25 & -0.05 & 0.08 \\
\hline IUPAC\#128 & 0.79 & 0.41 & -0.12 & -0.12 \\
\hline IUPAC\#138 & 0.58 & 0.74 & -0.01 & -0.15 \\
\hline IUPAC\#153 & 0.56 & 0.24 & -0.55 & -0.40 \\
\hline IUPAC\#156 & 0.67 & 0.53 & 0.03 & 0.13 \\
\hline IUPAC\#170 & 0.24 & 0.88 & -0.14 & 0.27 \\
\hline IUPAC\#180 & 0.16 & 0.92 & -0.06 & 0.20 \\
\hline IUPAC\#183 & 0.39 & 0.85 & -0.05 & 0.04 \\
\hline IUPAC\#187 & 0.49 & 0.78 & 0.00 & -0.14 \\
\hline IUPAC\#194 & 0.27 & 0.83 & -0.21 & 0.13 \\
\hline IUPAC\#195 & 0.20 & 0.76 & -0.31 & 0.32 \\
\hline$p^{\prime} p$-DDT & 0.30 & 0.62 & -0.18 & 0.48 \\
\hline$p^{\prime} p-\mathrm{DDE}$ & 0.16 & 0.38 & 0.22 & 0.05 \\
\hline$p^{\prime} p$-DDD & 0.21 & 0.24 & -0.10 & 0.78 \\
\hline $\mathrm{a}-\mathrm{HCH}$ & -0.16 & -0.12 & 0.82 & 0.01 \\
\hline b-HCH & 0.04 & -0.04 & 0.74 & -0.18 \\
\hline $\mathrm{c}-\mathrm{HCH}$ & -0.09 & -0.04 & 0.88 & -0.05 \\
\hline dieldrine & 0.77 & 0.24 & -0.27 & 0.17 \\
\hline $\mathrm{T}_{4}\left(\mathrm{ng} \mathrm{g}^{-1}\right)$ & $\begin{array}{l}R=-0.076 \\
n=87 \\
p=0.482\end{array}$ & $\begin{array}{l}R=0.055 \\
n=87 \\
p=0.613\end{array}$ & $\begin{array}{l}R=0.391 \\
n=87 \\
\boldsymbol{p}<\mathbf{0 . 0 0 1}\end{array}$ & $\begin{array}{l}R=-0.026 \\
n=87 \\
p=0.811\end{array}$ \\
\hline $\mathrm{T}_{3}\left(\mathrm{ng} \mathrm{g}^{-1}\right)$ & $\begin{array}{l}R=0.059 \\
n=87 \\
p=0.588\end{array}$ & $\begin{array}{l}R=-0.232 \\
n=87 \\
\boldsymbol{p}=\mathbf{0 . 0 3 0}\end{array}$ & $\begin{array}{l}R=0.490 \\
n=87 \\
\boldsymbol{p}<\mathbf{0 . 0 0 1}\end{array}$ & $\begin{array}{l}R=-0.307 \\
n=87 \\
\boldsymbol{p}=\mathbf{0 . 0 0 4}\end{array}$ \\
\hline Follicle diameter $(\mu \mathrm{m})$ & $\begin{array}{l}R=-0.101 \\
n=44 \\
p=0.515\end{array}$ & $\begin{array}{l}R=0.027 \\
n=44 \\
p=0.861\end{array}$ & $\begin{array}{l}R=0.115 \\
n=44 \\
p=0.459\end{array}$ & $\begin{array}{l}R=-0.232 \\
n=44 \\
\mathrm{p}=0.129\end{array}$ \\
\hline Cell height $(\mu \mathrm{m})$ & $\begin{array}{l}R=-0.094 \\
n=44 \\
p=0.543\end{array}$ & $\begin{array}{l}R=0.103 \\
n=44 \\
p=0.507\end{array}$ & $\begin{array}{l}R=0.180 \\
n=44 \\
p=0.242\end{array}$ & $\begin{array}{l}R=-0.300 \\
n=44 \\
\boldsymbol{p}=\mathbf{0 . 0 4 7}\end{array}$ \\
\hline Roundness & $\begin{array}{l}R=0.120 \\
n=44 \\
p=0.404\end{array}$ & $\begin{array}{l}R=-0.116 \\
n=44 \\
p=0.454\end{array}$ & $\begin{array}{l}R=-0.039 \\
n=44 \\
p=0.802\end{array}$ & $\begin{array}{l}R=0.161 \\
n=44 \\
p=0.307\end{array}$ \\
\hline Form factor & $\begin{array}{l}R=-0.193 \\
n=44 \\
p=0.210\end{array}$ & $\begin{array}{l}R=-0.027 \\
n=44 \\
p=0.863\end{array}$ & $\begin{array}{l}R=0.266 \\
n=44 \\
p=0.081\end{array}$ & $\begin{array}{l}R=-0.088 \\
n=44 \\
p=0.578\end{array}$ \\
\hline Aspect ratio & $\begin{array}{l}R=0.059 \\
n=87 \\
p=0.588\end{array}$ & $\begin{array}{l}R=-0.232 \\
n=87 \\
\boldsymbol{p}=\mathbf{0 . 0 3 0}\end{array}$ & $\begin{array}{l}R=0.490 \\
n=87 \\
\boldsymbol{p}<\mathbf{0 . 0 0 1}\end{array}$ & $\begin{array}{l}R=-0.307 \\
n=87 \\
\boldsymbol{p}=\mathbf{0 . 0 0 4}\end{array}$ \\
\hline Deiodinase activity (fmol $\min ^{-1} \mu \mathrm{g}^{-1}$ ) & $\begin{array}{l}R=0.179 \\
n=87 \\
p=0.106\end{array}$ & $\begin{array}{l}R=0.424 \\
n=87 \\
\boldsymbol{p}<\mathbf{0 . 0 0 1}\end{array}$ & $\begin{array}{l}R=-0.334 \\
n=87 \\
\boldsymbol{p}=\mathbf{0 . 0 0 2}\end{array}$ & $\begin{array}{l}R=0.046 \\
n=87 \\
p=0.682\end{array}$ \\
\hline Sulfation activity (fmol $\min ^{-1} \mu \mathrm{g}^{-1}$ ) & $\begin{array}{l}R=0.435 \\
n=20 \\
p=0.071\end{array}$ & $\begin{array}{l}R=-0.478 \\
n=20 \\
\boldsymbol{p}=\mathbf{0 . 0 4 5}\end{array}$ & $\begin{array}{l}R=-0.092 \\
n=20 \\
p=0.715\end{array}$ & $\begin{array}{l}R=-0.072 \\
n=20 \\
p=0.775\end{array}$ \\
\hline Glucuronidation activity ( $\mathrm{fmol} \mathrm{min}^{-1} \mu \mathrm{g}^{-1}$ ) & $\begin{array}{l}R=0.119 \\
n=20 \\
p=0.639\end{array}$ & $\begin{array}{l}R=-0.100 \\
n=20 \\
p=0.693\end{array}$ & $\begin{array}{l}R=0.401 \\
n=20 \\
p=0.099\end{array}$ & $\begin{array}{l}R=0.433 \\
n=20 \\
p=0.073\end{array}$ \\
\hline
\end{tabular}

2011) and thyroid parameters. The current study demonstrates that exposure to a mixture of organochlorine compounds has effects on thyroid hormone status in juvenile sea bass. The muscular $\mathrm{T}_{3}$ and $\mathrm{T}_{4}$ concentration were lower in sea bass from more polluted areas (coastal regions near river Seine and Scheldt) (Fig. 4A-C). This observation correlates with the chlorination level of PCB congeners and the DDTs concentrations. In vertebrates, thyroid gland activity is homeostatically regulated by the brain (hypothalamus)-pituitarythyroid axis. A key thyrotropic signal is thyroid stimulating hormone
(TSH) from the pituitary pars distalis, which controls synthesis, storage and secretion of $\mathrm{T}_{4}$ in a classical negative feedback system (Brown et al., 2004; Blanton and Specker, 2007; Zoeller et al., 2007). Measurements of follicular diameter and epithelial cell heights showed that higher contamination levels were capable of temporarily inducing a mild hypertrophy, indicating an increase of synthesis and secretion activity of the gland.

The dynamic relationship among hormones secreted by the HPT axis has the effect of maintaining thyroid levels within a narrow 


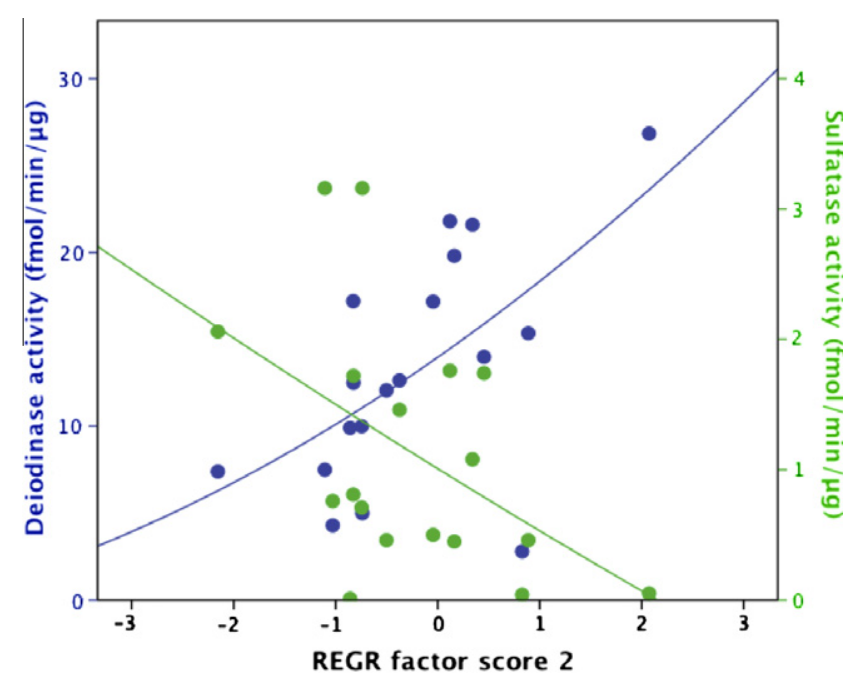

Fig. 3. Correlation between REGR factor score 2 (reflecting concentration $\mu \mathrm{g} \mathrm{g}^{-1}$ ww of highly chlorinated PCB congeners (Schnitzler et al., 2011)) and the hepatic deiodinase and sulfatation activity.

range. Both, $\mathrm{T}_{4}$ and $\mathrm{T}_{3}$ have a negative feedback effect on TSH secretion by the pituitary in teleost fish species (Yoshiura et al., 1999). Plasma levels of TSH are difficult to measure and rarely reported in fish studies (Kumar et al., 2000). Because of the species differences in the primary structure of TSH and the degree of glycosylation, mammalian antibodies typically do not recognize non-mammalian TSH and homologous antisera are not available for the majority of teleost species. In our field study a certain thyroid homeostasis could be maintained, even when a slight decrease of $\mathrm{T}_{4}$ could be observed in higher contaminated wild sea bass. Serum half-life of thyroxin $\left(T_{4}\right)$ is controlled in part by serum binding proteins like ThyroxinBinding-Globulin (TBG), Transthyretin (TTR) and albumin. PCBs and related compounds are structurally similar to thyroid hormones and are well known to displace $\mathrm{T}_{4}$ from serum binding proteins (Lans et al., 1994; Brouwer et al., 1998; Brucker-Davis, 1998; Funkenstein et al., 2000; Marino and McCluskey, 2000; Ishihara et al., 2003; Boas et al., 2006; Kashiwagi et al., 2009). This may cause a decline in serum thyroid hormone concentration by biliary clearance, inducing a release of TSH provoking the observed increase of synthesis and secretion activity of the gland. This observation has led to the concept that the negative feedback loop of the HPT axis can compensate for dysfunction of the thyroid gland (Zoeller et al., 2007).

Peripheral $\mathrm{T}_{3}$ levels in teleost fish are largely controlled by enzymatic 5'-deiodination activities in extra-thyroidal tissues (such as liver, brain, kidney and gill) that control the conversion of $\mathrm{T}_{4}$ to the biologically active form $\mathrm{T}_{3}$, and other enzymes involved in extra-thyroidal metabolism (Brown et al., 2004). Fish liver expresses the highest $\mathrm{T}_{4} \mathrm{ORD}$ activity, which support the notion that liver could play a dual role, contributing to both the local and systemic supply of $\mathrm{T}_{3}$ (Blanton and Specker, 2007). A slight depression in deiodinating activities can have severe consequences, as kinetic studies showed that about $80 \%$ of the $\mathrm{T}_{3}$ in salmonids reside in a slowly exchanging reserve pool, mainly represented by skeletal muscle (Brown et al., 2004). Exposure of rats to PCBs resulted in an inhibition of hepatic deiodinase activity (Visser et al., 1993; Morse et al., 1996; Brouwer et al., 1998). Our findings support the hypothesis of the disturbance of the peripheral control of thyroid hormone homeostasis. Higher chlorinated PCB congeners and DDTs increased hepatic $\mathrm{T}_{4} \mathrm{ORD}$ activity while decreasing the hepatic sulfatation activity. Similar observations have been made in American plaice (Hippoglossoides platessoides) (Adams et al., 2000). It was concluded that the PCB-induced changes in deiodinating activity
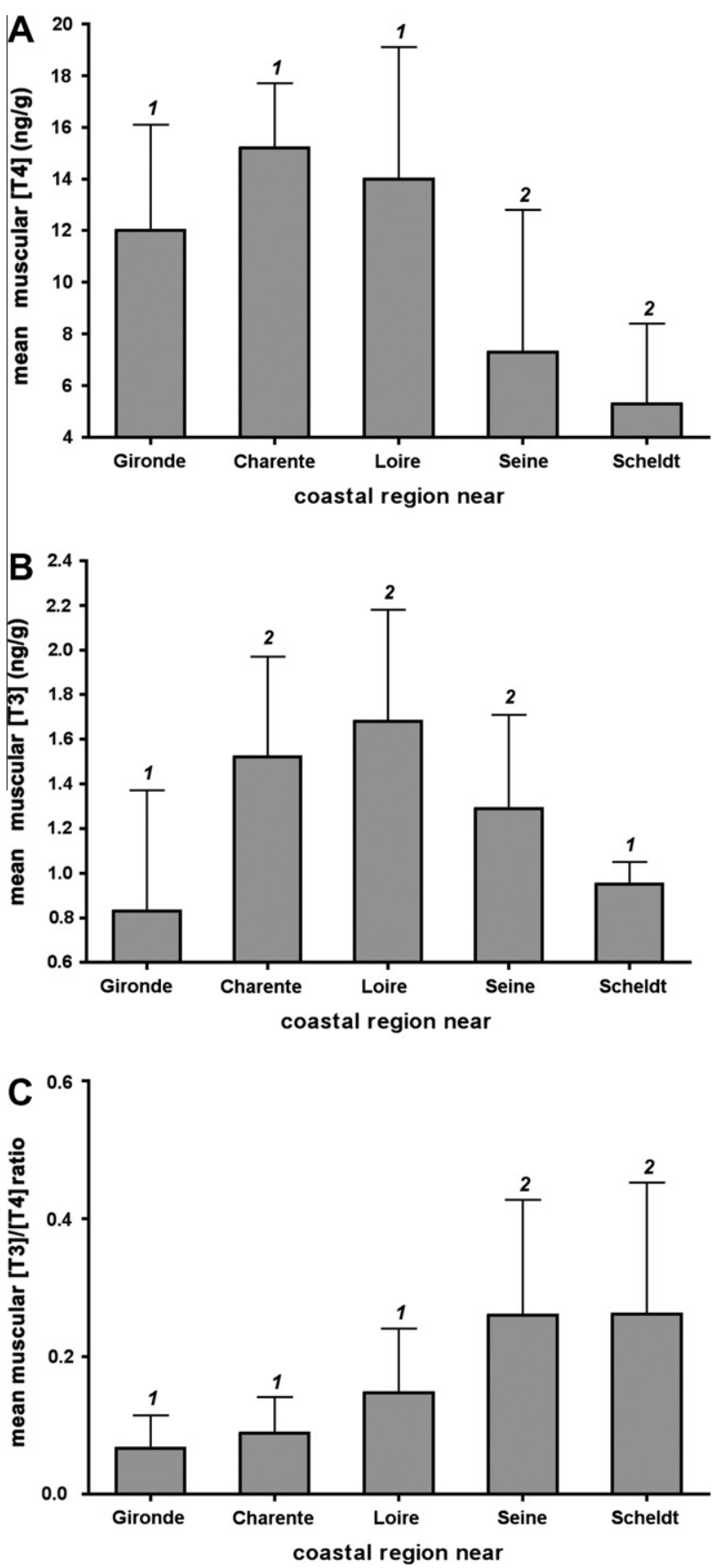

Fig. 4. Differences in muscular thyroid hormone concentrations (A: mean $T_{4}$ $\left(\mathrm{ng} \mathrm{g}^{-1}\right), \mathrm{B}$ : mean $\mathrm{T}_{3}\left(\mathrm{ng} \mathrm{g}^{-1}\right)$, and $\mathrm{C}: \mathrm{T}_{3} / \mathrm{T}_{4}$ ratio; all with standard deviation) in sea bass from coastal regions near European river mouths.

likely represents compensatory responses to disrupting effects that might otherwise have depressed the plasma $\mathrm{T}_{3}$ levels. The different responses between mammalian and fish species rests on the fact that in fish the $T_{3}$ levels are primarily under peripheral control.

Thyroid hormones are conjugated by sulfatation and glucuronidation. These Phase II reactions are usually detoxificating in nature, and involve the interactions of the polar functional groups of phase I metabolites (Schuur et al., 1999). Sulfotransferases inactivate thyroid hormones and facilitate their excretion in bile and urine. Furthermore, thyroid hormone sulfates do not bind to $\mathrm{T}_{3}$ receptors and are thus unable to mimic $\mathrm{T}_{3}$ activity and are rapidly degraded by inner ring deiodinases (Brouwer et al., 1998; Schuur 
et al., 1999). We observed a slight decrease of SULT activity in liver of sea bass from higher contaminated regions. This is in accordance with in vitro studies using rat and human hepatoma cell lines that related a strong inhibition of thyroid hormones sulfatation by hydroxylated metabolites of PCB (Brouwer et al., 1998; Schuur et al., 1999).

DDT metabolites exert the same effects on muscular thyroid hormone concentrations and deiodination activity, but especially the DDD metabolite seem to induce changes in thyroid histological appearance. Sea bass from higher DDD contaminated regions showed a decrease in thyroid cell height. Similar effects are reported in mullet (L. parsia) exposed to DDT (Brown et al., 2004).

The isomers of hexachlorocyclohexane $(\mathrm{HCH})$, had opposite effects on the thyroid system. Similar results are reported from catfish ( $H$. fossilis), $\mathrm{HCH}$ induced an increase of muscular $\mathrm{T}_{4}$ and $\mathrm{T}_{3}$ levels while the hepatic $\mathrm{T}_{4} \mathrm{ORD}$ activity was reduced and no changes in histological appearance could be related (Yadav and Singh, 1987). No effect on thyroid hormone levels could be reported from rainbow trout (O. mykiss) (Aldegunde et al., 1999) and thyroid hypertrophy was reported in medaka (O. latipes) (Wester and Canton, 1988) in association with an $\mathrm{HCH}$ exposure. The $\mathrm{HCHs}$ contribute only for less than $0.5 \%$ of the total muscular organochlorine contamination of the tested fish.

\section{Conclusions}

This study was designed to control factors known to influence thyroid hormones, including age, gender, diet, nutritional status, season and physiological condition. We established correlations between contaminant concentrations and effects on the thyroid endocrine system in sea bass from the major European coastal regions. Fish from polluted sites carrying high levels of contaminants showed significant differences in thyroidal status. The enzymatic activity of hepatic $\mathrm{T}_{4}$ outer ring deiodinase and $\mathrm{T}_{4}$ sulfatation was altered whereas $\mathrm{T}_{4}$ glucuronidation was not affected. Muscular $\mathrm{T}_{4}$ levels were preserved despite a slight diminution in $\mathrm{T}_{3}$ concentration. These observations suggest specific effects of highly chlorinated PCB congeners. The preservation of thyroid hormone levels probably reflects a tight homeostatic control of $\mathrm{T}_{4}$. Changes in hormonal dynamics lead to an increased conversion of $\mathrm{T}_{4}$ to $\mathrm{T}_{3}$ and a reduced excretion of thyroid hormones. These results support the hypothesis that adaptations of metabolic pathways of thyroid hormones can be interpreted as a pathway to homeostatically maintain thyroid hormone status.

\section{Acknowledgements}

Schnitzler, J. received grants from FRIA (Fonds pour la formation à la recherche dans l'industrie et dans l'agriculture). Das, K. is a F.R.S-FNRS Research Associate. The authors thank Murielle, L. from the Laboratoire d'Ecologie animale et d'Ecotoxicologie, University of Liege (Belgium) for valuable help during the chemical analysis. Special thanks go to the chief scientists and teams of the IFREMER CGFS2007 cruise Schlaich, I., as well as of the IFREMER EVHOE2007 cruise Bellail, R., and Mahe, J-C., and Breine, J., from INBO. MARE is the Interfacultary center for marine research of the University of Liège This is a MARE publication 220.

\section{References}

Adams, B.A., Cyr, D.G., Eales, J.G., 2000. Thyroid hormone deiodination in tissues of American plaice, hippoglossoides platessoides: characterization and short-term responses to polychlorinated biphenyls (PCBs) 77 and 126. Comp. Biochem. Physiol. C Pharmacol. Toxicol. Endocrinol. 127, 367-378.

Aldegunde, M., Soengas, J., Ruibal, C., Andres, M., 1999. Effects of chronic exposure to gamma-HCH (lindane) on brain serotonergic and gabaergic systems, and serum cortisol and thyroxine levels of rainbow trout, Oncorhynchus mykiss. Fish Physiol. Biochem. 20, 325-330.
Bernier, N.J., Flik, G., Klaren, P.H.M., 2009. Regulation and Contribution of the Corticotropic, Melanotropic and Thyrotropic Axes to the Stress Response in Fishes. In: Bernier DGVDKDAPF, Dr. Nicholas J., Dr. Colin, J.B., Colin, Dr. (Eds.), Fish Physiology. Academic Press, pp. 235-311 (Chapter 6).

Besselink, H., vanBeusekom, S., Roex, E., Vethaak, A., Koeman, J., Brouwer, A, 1996. Low hepatic 7-ethoxyresorufin-O-deethylase (EROD) activity and mino alterations in retinoid and thyroid hormone levels in flounder (Platichthys flesus) exposed to the polychlorinated biphenyl (PCB) mixture, Clophen A50. Environ. Pollut. 92, 267-274.

Blanton, M.L., Specker, J.L., 2007. The Hypothalamic-Pituitary-Thyroid (HPT) axis in fish and its role in fish development and reproduction. Crit. Rev. Toxicol. 37, 97-115.

Boas, M., Feldt-Rasmussen, U., Skakkebaek, N.E., Main, K.M., 2006. Environmental chemicals and thyroid function. Eur. J. Endocrinol. 154, 599-611.

Brouwer, A., Morse, D.C., Lans, M.C., Schuur, A.G., Murk, A.J., Klasson-Wehler, E., Bergman, A., Visser, T.J., 1998. Interactions of Persistent Environmental Organohalogens with the Thyroid Hormone System: Mechanisms and Possible Consequences for Animal and Human Health. Princeton Scientific Publ. Inc.. pp. 59-84.

Brown, S.B., Adams, B.A., Cyr, D.G., Eales, J.G., 2004. Contaminant effects on the teleost fish thyroid. Environ. Toxicol. Chem. 23, 1680-1701.

Brucker-Davis, F., 1998. Effects of environmental synthetic chemicals on thyroid function. Thyroid 8, 827-856.

de Jesus, E.G.T., Hirano, T., 1992. Changes in whole body concentrations of cortisol, thyroid hormones, and sex steroids during early development of the chum salmon, Oncorhynchus keta. Gen. Comp. Endocrinol. 85, 55-61.

Eales, J.G., Brown, S.B., 1993. Measurement and regulation of thyroidal status in teleost fish. Rev. Fish Biol. Fisheries 3, 299-347.

Fok, P., Eales, J., Brown, S., 1990. Determination of 3,5,3'-Triiodo-L-thyronine (T3) levels in tissues of rainbow trout (Salmo gairdneri) and the effect of low ambient pH and aluminium. Fish Physiol. Biochem. 8, 281-290.

Funkenstein, B., Bowman, C.J., Denslow, N.D., Cardinali, M., Carnevali, O., 2000 Contrasting effects of estrogen on transthyretin and vitellogenin expression in males of the marine fish, Sparus aurata. Mol. Cell. Endocrinol. 167, 33-41.

Howdeshell, K., 2002. A model of the development of the brain as a construct of the thyroid system. Environ. Health Perspect. 110, 337-348.

Ishihara, A., Sawatsubashi, S., Yamauchi, K., 2003. Endocrine disrupting chemicals: interference of thyroid hormone binding to transthyretins and to thyroid hormone receptors. Mol. Cell. Endocrinol. 199, 105-117.

Janz, D.M., 2000. Gross Functional Anatomy: Endocrine System. In: Ostrander, G.K. (Ed.), The Handbook of Experimental Animals - Laboratory Fish. Academic Press, London, UK, pp. 189-217.

Kashiwagi, K., Furuno, N., Kitamura, S., Ohta, S., Sugihara, K., Utsumi, K., Hanada, H., Taniguchi, K., Suzuki, K., Kashiwagi, A., 2009. Disruption of thyroid hormone function by environmental pollutants. J. Health Sci. 55, 147-160.

Klaren, P.H.M., Haasdijk, R., Metz, J.R., Nitsch, L.M.C., Darras, V.M., Van der Geyten, S., Flik, G., 2005. Characterization of an iodothyronine $5^{\prime}$-deiodinase in gilthead seabream (Sparus auratus) that is inhibited by dithiothreitol. Endocrinology 146, 5621-5630.

Kumar, R., Ijiri, S., Kight, K., Swanson, P., Dittman, A., Alok, D., 2000. Cloning and functional expression of a thyrotropin receptor from the gonads of a vertebrate (bony fish): potential thyroid-independent role for thyrotropin in reproduction. Mol. Cell. Endocrinol. 167, 1-9.

Lans, M., Spiertz, C., Brouwer, A., Koeman, J., 1994. Different competition of thyroxine-binding to transthyretin and thyroxine-binding globulin by hydroxyPCBs, PCDDs and PCDFs. Eur. J. Pharmacol. Environ. Toxicol. Pharmacol. Sect. $270,129-136$.

Leatherland, J.F., 1993. Field observation on reproductive and developmental dysfunction in introduced and native salmonids from the great lakes. Histochem. J. 19, 737-751.

Leatherland, J.F., Down, N.E., 2001. Tumours and related lesions of the endocrine system of bony and cartilaginous fishes. Fish Fish. 2, 59-77.

Leatherland, J.F., Lin, L., Down, N.E., Donaldson, E.M., 1989a. Thyroid hormone content of eggs and early developmental stages of three stocks of goitred coho salmon (Oncorhynchus kisutch) from the great lakes of north America, and a comparison with a stock from British Columbia. Can. J. Fish. Aquat. Sci. 46, $2146-2152$.

Leatherland, J.F., Lin, T.H., Down, N.E., Donaldson, E.M., 1989b. Thyroid hormone content of eggs and early development stages of five Oncorhynchus species. Can. J. Fish. Aquat. Sci. 46, 2140-2145.

Leatherland, J.F., Sonstegard, R.A., 1978. Lowering of serum thyroxine and triiodothyronine levels in yearling coho salmon by dietary mirex and PCBs. J. Fish. Res. Board Can. 35, 1285-1289.

Leatherland, J.F., Sonstegard, R.A., 1980. Effect of dietary polychlorinated biphenyls (PCBs) or mirex in combination with food deprivation and testosterone administration on serum thyroid hormone concentration and bioaccumulation of organochlorines in rainbow trout, Salmo gairdneri. J. Fish. Dis. 3, 115-124.

Leroy, K., Thomas, P., Khan, I., 2006. Thyroid hormone status of Atlantic croaker exposed to Aroclor 1254 and selected PCB congeners. Comp. Biochem. Physiol. C. Toxicol. Pharmacol. 144, 263-271.

Lewis, M.A., Scott, G.I., Bearden, D.W., Quarles, R.L., Moore, J., Strozier, E.D., Sivertsen, S.K., Dias, A.R., Sanders, M., 2002. Fish tissue quality in near-coastal areas of the gulf of Mexico receiving point source discharges. Sci. Total Environ. 284, 249-261.

Loizeau, V., 2001. A steady-state model of PCB bioaccumulation in the sea bass (Dicentrarchus labrax) food web from the Seine estuary, France. Estuaries 24 1074-1087. 
Marino, M., McCluskey, R.T., 2000. Role of thyroglobulin endocytic pathways in the control of thyroid hormone release. Am. J. Physiol. Cell Physiol. 279, C1295-1306.

Morse, D.C., Wehler, E.K., Wesseling, W., Koeman, J.H., Brouwer, A., 1996. Alterations in rat brain thyroid hormone status following pre- and postnatal exposure to polychlorinated biphenyls (Aroclor 1254). Toxicol. Appl. Pharmacol. $136,269-279$

Naso, B., Perrone, D., Ferrante, M.C., Bilancione, M., Lucisano, A., 2005. Persistent organic pollutants in edible marine species from the gulf of Naples, southern Italy. Sci. Total Environ. 343, 83-95.

Pandey, A., George, K., Mohamed, M., 1995. Effect of DDT on the thyroid gland of the mullet Liza parsia. J. Mar. Biol. Assoc. India 37, 287-290.

Parker, S., Specker, J., 1990. Salinity and temperature effects on whole-animal thyroid-hormone levels in larval and juvenile stripped bass, Morone Saxatilis. Fish Physiol. Biochem. 8, 507-514.

Power, D.M., Llewellyn, L., Faustino, M., Nowell, M.A., Björnsson, B.T., Einarsdottir, I.E., Canario, A.V.M., Sweeney, G.E., 2001. Thyroid hormones in growth and development of fish. Comp. Biochem. Physiol. C: Toxicol. Pharmacol. 130, 447459.

Raine, J., 2001. Assessment of thyroid function in adult medaka (Oryzias latipes) and juvenile rainbow trout (Oncorhynchus mykiss) using immunostaining methods. J. Exp. Zool. 290, 366-378.

Rolland, R., 2000. A review of chemically-induced alterations in thyroid and vitamin A status from field studies of wildlife and fish. J. Wildl. Dis. 36, 615-635.

Schnitzler, J.G., Koutrakis, E., Siebert, U., Thomé, J.P., Das, K., 2008. Effects of persistent organic pollutants on the thyroid function of the European sea bass (Dicentrarchus labrax) from the Aegean sea, is it an endocrine disruption? Mar Pollut. Bull. 56, 1755-1764.

Schnitzler, J.G., Thomé, J.P., Lepage, M., Das, K., 2011. Organochlorine pesticides and polychlorinated biphenyl residues in wild sea bass (Dicentrarchus labrax) off European estuaries. Sci. Total Environ. 409, 3680-3686.

Schuur, A.G., Bergman, Å., Brouwer, A., Visser, T.J., 1999. Effects of pentachlorophenol and hydroxylated polychlorinated biphenyls on thyroid hormone conjugation in a rat and a human hepatoma cell line. Toxicol. In Vitro 13, 417-425.

Shukla, L., Pandey, A.K., 1986. Restitution of thyroid activity in the DDT exposed\&lt;i\&gt:Sarotherodon Massambicus\&lt;/i\&gt;: A histological an histochemical profile. Water Air Soil Pollut. 27, 225-236.
Tagawa, M., Hirano, T., 1987. Presence of thyroxine in eggs and changes in its content during early development of chum salmon, Oncorhynchus keta. Gen. Comp. Endocrinol. 68, 129-135.

Tagawa, M., Miwa, S., Inui, Y., Dejesus, E., Hirano, T., 1990a. Changes in thyroidhormone concentrations during early development and metamorphosis of the flounder, Paralichthys olivaceus. Zool. Sci. 7, 93-96.

Tagawa, M., Tanaka, M., Matsumoto, S., Hirano, T., 1990b. Thyroid-hormones in eggs of various freshwater, marine and diadromous teleosts and their changes during egg development. Fish Physiol. Biochem. 8, 515-520.

van der Heide, S., Visser, T., Everts, M., Klaren, P., 2002. Metabolism of thyroid hormones in cultured cardiac fibroblasts of neonatal rats. J. Endocrinol. 174, 111-119.

Visser, T.J., Kaptein, E., Vantoor, H., Vanraaij, J., Vandenberg, K.J., Joe, C.T.T., Vanengelen, J.G.M., Brouwer, A., 1993. Glucuronidation of thyroid-hormone in rat-liver - effects of in-vivo treatment with microsomal-enzyme inducers and in-vitro assay conditions. Endocrinology 133, 2177-2186.

Weber, G.M., Okimoto, D.K., Richman, N.H., Grau, E.G., 1992. Patterns of thyroxine and triiodothyronine in serum and follicle-bound oocytes of the tilapia, Oreochromis mossambicus, during oogenesis. Gen. Comp. Endocrinol. 85, 392404

Wester, P., Canton, J., 1988. Histopathology of P. reticulata (Guppy) and Oryzias latipes (Medaka) in toxicity testing of some environmental contaminants. Aquat. Toxicol. 12, 323-344.

Yadav, A., Singh, T., 1987. Pesticide induced changes in peripheral thyroid hormone levels during different reproductive phases in Heteropneustes fossilis. Ecotoxicol. Environ. Saf. 13, 97-103.

Yamano, K., 2005. The role of thyroid hormone in fish development with reference to aquaculture. JARQ 39, 161-168.

Yamano, K., Tagawa, M., de Jesus, E.G.T., Hirano, T., Miwa, S., Inui, Y., 1991. Changes in whole body concentrations of thyroid hormones and cortisol in metamorphosing conger eel. J. Comp. Physiol. B 161, 371-375.

Yoshiura, Y., Sohn, Y., Munakata, A., Kobayashi, M., Aida, K., 1999. Molecular cloning of the cDNA encoding the beta subunit of thyrotropin and regulation of its gene expression by thyroid hormones in the goldfish, Carassius auratus. Fish Physiol. Biochem. 21, 201-210.

Zoeller, R.T., Tan, S.T., Tyl, R.W., 2007. General background on the HypothalamicPituitary-Thyroid (HPT) axis. Crit. Rev. Toxicol. 37, 11-53. 